\title{
PENGARUH JUMLAH TEPUNG KANJI PADA PEMBUATAN BRIKET ARANG TEMPURUNG PALA
}

\author{
THE EFFECT OF TAPIOCA STARCH VARIATION ON \\ NUTMEG-SHELL CHARCOAL BRIQUETTE PREPARATION
}

\author{
Petrus Patandung \\ Balai Riset dan Standardisasi Industri Manado \\ Jalan Diponegoro No.21-23 \\ Pos-el : patandungp@yahoo.com
}

Diterima Tanggal 26-10-2014, Disetujui Tanggal 9-11-2014

\begin{abstract}
ABSTRAK
Penelitian pembuatan briket arang tempurung pala telah dilaksanakan dengan tujuan untuk mengetahui pengaruh jumlah tepung kanji terhadap mutu briket yg dihasilkan, sehingga dapat digunakan sebagai bahan bakar. Briket dibuat menggunakan arang tempurung pala dengan perekat tepung kanji sebanyak 2; 2,5; 3; 3,5 dan 4\%, dan tekanan $150 \mathrm{~kg} / \mathrm{cm}^{2}$. Dari penelitian ini diperoleh bahwa arang tempurung pala dapat diolah menjadi briket. Briket yang dihasilkan mempunyai kisaran kadar air sebesar 6,11-6,50\%, bagian yang hilang pada pemanasan suhu $950{ }^{\circ} \mathrm{C}$ sebesar $14,20-14,80 \%$, kadar abu sebesar 5,45-5,94\%, dan nilai kalori sebesar 5.047,27-5.219,00 kal/g.

Kata kunci: briket, tempurung pala, kanji, nilai kalori.
\end{abstract}

\section{ABSTRACT}

A research on nutmeg-shell charcoal briquettes has been conducted to determine the effect of starch amount on the quality of product. Charcoal briquettes were made using adhesive as much as 2\%; 2.5\%; 3\%; 3.5\%; and 4\%, and a pressure of $150 \mathrm{~kg} / \mathrm{cm}^{2}$. Results showed that charcoal nutmeg-shell can be processed into briquettes, with a range of moisture of 6.11-6.50\%, volatiles at $950{ }^{\circ} \mathrm{C}$ of $14.20-14.80 \%$, ash content of $5.45-5.94 \%$ and calorie of $5047.27-5219.00$ $\mathrm{cal} / \mathrm{g}$.

Keywords: briquette, calorie, nutmeg-shell, tapioca starch.

\section{PENDAHULUAN}

Tanaman pala (Myristica fragrans Houtt) adalah salah satu tanaman andalan Sulawesi Utara karena biji dan fulinya merupakan komoditi ekspor yang kebanyakan tumbuh di pesisir pantai kepulauan dengan data luas areal adalah 13.774,49 ha dengan produksi 9.645,56 ton, dari luas areal tersebut tersebar di beberapa Kabupaten, seperti Kabupaten Sangihe 3.351,53 ha dengan produksi 2.665,07 ton, Kabupaten Talaud memiliki perkebunan pala seluas 4.877 ha dengan produksi $3.218,09$ ton dan Kabupaten
Sitaro memiliki perkebunan pala seluas 4.418 ha dengan produksi sebesar $3.321,15$ ton (1).

Tanaman pala adalah salah satu tanaman rempah-rempah yang produknya berasal dari daging buah yang merupakan bagian yang terbesar adalah daging buah yaitu $83,30 \%$, fuli $3,20 \%$, biji $9,50 \%$ dan tempurung biji 4\% (2).

Limbah tempurung pala belum dimanfaatkan secara maksimal dan hanya digunakan sebagai bahan bakar atau pemasakan kedelai untuk pembuatan tempe dan tahu, padahal masih dapat 
diolah sedemikian rupa menjadi produk industri seperti pembuatan briket sebagai bahan bakar yang dapat mengganti bahan bakar minyak tanah dan gas elpiji.

Briket arang merupakan bahan bakar padat dengan menggunakan perekat dan tekanan, mengandung senyawa karbon, mempunyai nilai kalori yang relatif tinggi, dan dapat menyala dalam waktu yang cukup lama (3).

Perkembangan energi baru dan terbarukan merupakan suatu energi alternative yang berbahan biomassa yang dapat dikembangkan lebih lanjut menjadi bahan bakar padat atau briket.

Biomassa adalah salah satu jenis bahan bakar padat yang berasal dari sumber hayati seperti dari daunan, rumput, limbah pertanian dan rumah tangga. Biomassa terdiri dari 2 (dua) macam yaitu: berasal dari kayu dan non kayu (4). Cadangan gas alam menunjukkan bahwa 47,5\% kebutuhan energi di Indonesia dipenuhi oleh bahan bakar minyak yang harganya semakin mahal sehingga dapat mendorong untuk mencari sumber energi alternatif seperti pemanfaatan limbah tempurung pala. Sebagian besar rumah tangga kebutuhan energinya masih mengandalkan minyak tanah dan gas elpiji. Saat ini cadangan minyak bumi Indonesia tinggal $1 \%$ dan cadangan dunia tinggal 1,4\% , sedangkan batu bara sebagai bahan bakar hanya tinggal $3 \%(5)$. Dari data tersebut dapat diperkirakan beberapa tahun lagi Indonesia akan mengimpor penuh minyak bumi. oleh karena itu usaha untuk mencari bahan bakar alternatif yang dapat diperbaharui yang bersifat ramah lingkungan, dan bernilai ekonomis (6).
Tujuan penelitian ini adalah untuk mengetahui pengaruh jumlah tepung kanji untuk pembuatan briket dari arang tempurung pala sehingga produk yang diperoleh dapat digunakan sebagai bahan bakar pengganti minyak tanah dan gas elpiji.

\section{BAHAN DAN METODE}

\section{Bahan dan Alat}

Bahan yang digunakan yaitu bahan tempurung pala, tepung kanji, minyak tanah, sedangkan alat yang digunakan yaitu mesin giling, alat pencampur, alat cetak, pengering briket, baskom plastik kompor dan timbangan.

\section{Tempat dan Waktu}

Penelitian dilaksanakan di Balai Riset dan Standardisasi Industri Manado, dari bulan Februari sampai dengan Nopember 2012.

\section{Metode penelitian}

Penelitian ini menggunakan desain percobaan membuat briket dengan variasi konsentrasi perekat tepung kanji yaitu: $A=2 \%, B=2,5 \%, C=3 \%, D=3,5 \%$ dan $E=4 \%$ dan tekanan $150 \mathrm{~kg} / \mathrm{cm}^{2}$. Data dianalisis secara deskriptif. Penelitian diulang 3 kali.

\section{Tahapan Penelitian}

Tempurung pala yang telah kering ditimbang kemudian dikarbonisasi atau dibakar dalam drum pembakaran kemudian didinginkan sehingga diperoleh arang tempurung pala, dan digiling serta diayak lewat ukuran 18 mesh kemudian ditimbang sesuai dengan perlakuan. Tepung kanji ditimbang dan dimasak 
sampai homogen sehingga membentuk pasta kemudian dicampur dengan arang tempurung pala hingga merata dan ditambahkan air panas secukupnya lalu dicetak dengan menggunakan alat cetak briket sistem hidrolik dengan tekanan 150 $\mathrm{kg} / \mathrm{cm}^{2}$.

Produk briket arang tempurung pala dikeringkan dengan sinar matahari selama 3-4 hari, kemudian produk briket arang tempurung pala dikemas dalam plastik untuk dianalisis. Parameter yang diukur yaitu: Kadar air, kadar abu, bahan yang hilang pada pemanasan $950{ }^{\circ} \mathrm{C}$ dan nilai kalori.

\section{HASIL DAN PEMBAHASAN}

\section{Kadar Air}

Kadar air adalah banyaknya air yang masih terkandung dalam produk briket arang tempurung pala sehingga air yang terperangkap di dalam molekul-molekul partikel arang tempurung pala yang pada saat pengeringan produk tidak dapat keluar secara sempurna serta sejumlah air yang terperangkap didalam bahan perekat tepung kanji yang digunakan (7).

Hasil analisis produk briket tempurung pala (Gambar 1) menunjukkan bahwa kadar air dari produk briket arang tempurung pala yang diperoleh memberikan hasil yang tertinggi diperoleh pada perlakuan $E$ dengan menggunakan kanji sebanyak $4 \%$ yaitu sebesar $6,50 \%$ dan yang terendah diperoleh pada perlakuan A yaitu sebesar $6,11 \%$ dengan menggunakan penambahan kanji $2 \%$.

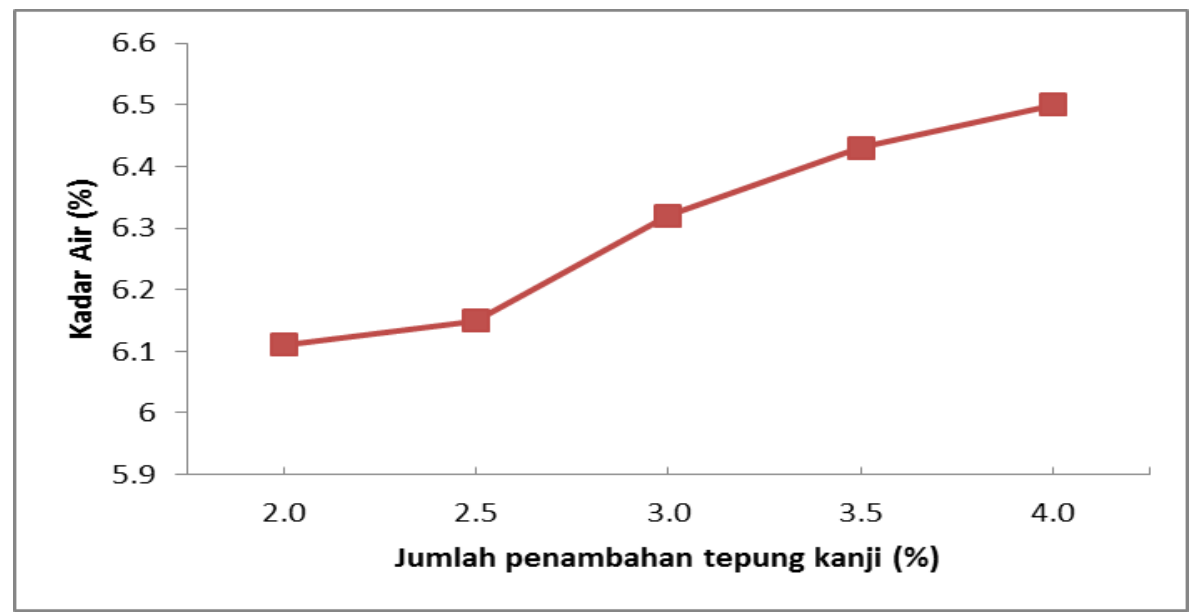

Gambar 1. Pengaruh penambahan tepung kanji terhadap kadar air Dari produk briket tempurung pala

Kenaikan hasil kadar air yang diperoleh disebabkan oleh penambahan bahan perekat yang digunakan yaitu tepung kanji dan juga dipengaruhi oleh penambahan air sehingga pada waktu dengan menggunakan sinar matahari proses pengeringan tidak merata yang mengakibatkan penguapan air tidak merata keseluruh permukaan dan seluruh bidang produk briket (8). 


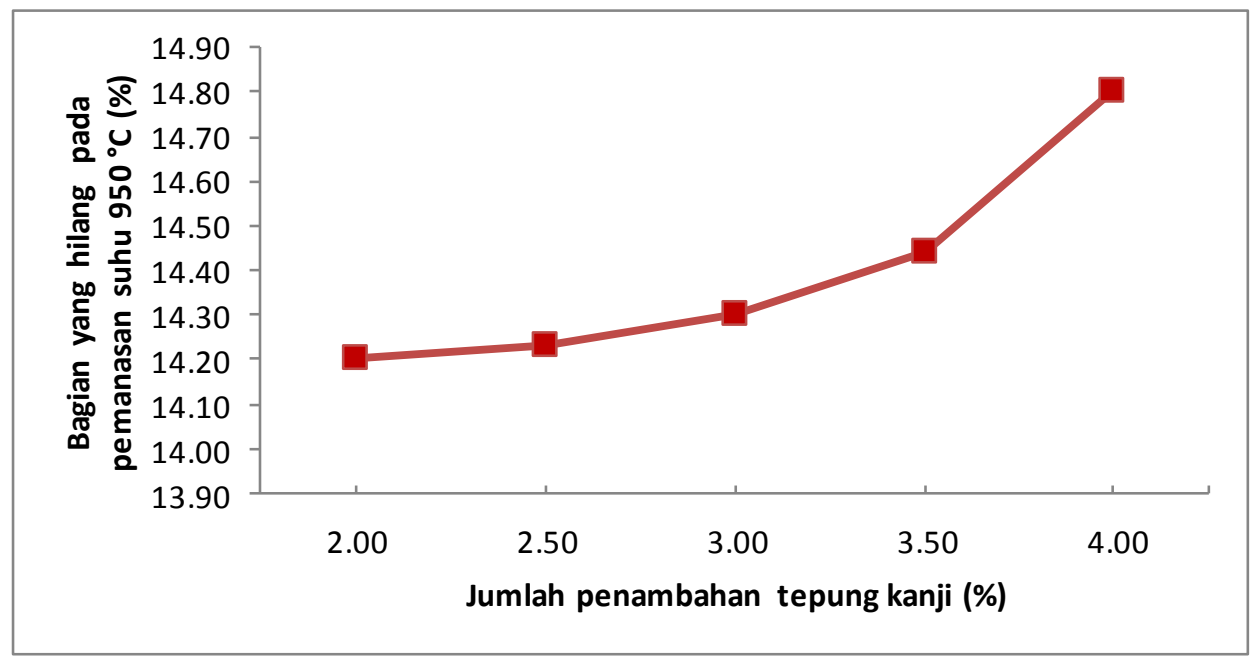

Gambar 2. Pengaruh penambahan tepung kanji terhadap bahan mudah menguap pada suhu

\section{Bagian Yang Hilang Pada Pemanasan $950{ }^{\circ} \mathrm{C}$}

Bagian yang hilang pada pemanasan suhu $950{ }^{\circ} \mathrm{C}$ atau bahan yang mudah menguap adalah jumlah zat-zat organik yang terikat dalam arang tempurung pala dan akan menguap pada suhu $950^{\circ} \mathrm{C}$.

Hasil analisis produk briket arang tempurung pala (Gambar 2) menunjukkan bahwa produk briket yang diperoleh memberikan hasil yang tertinggi pada perlakuan $\mathrm{E}$ dengan menggunakan tepung kanji $4 \%$ yaitu sebesar $14,80 \%$, dan yang terendah diperoleh pada perlakuan $A$ dengan menggunakan perekat tepung kanji $2 \%$, menghasilkan produk briketarang tempurung pala sebesar $14,20 \%$.
Tinggi dan rendahnya bagian yang hilang pada pemanasan $950{ }^{\circ} \mathrm{C}$ disebabkan oleh bahan baku atau tempurung pala yang digunakan sehingga pada waktu proses karbonisasi atau pembuatan arang tempurung pala menggunakan pemanasan atau suhu yang tidak diatur yang mengakibatkan tidak terjadinya penguraian senyawa karbon yang sempurna dan bahan volatil yang terkandung dalam kanji lebih tinggi (9).

\section{Kadar Abu}

Kadar abu adalah jumlah abu yang terkandung dalam bahan baku arang tempurung pala dan juga yang terdapat dalam bahan perekat yaitu tepung kanji (10). 


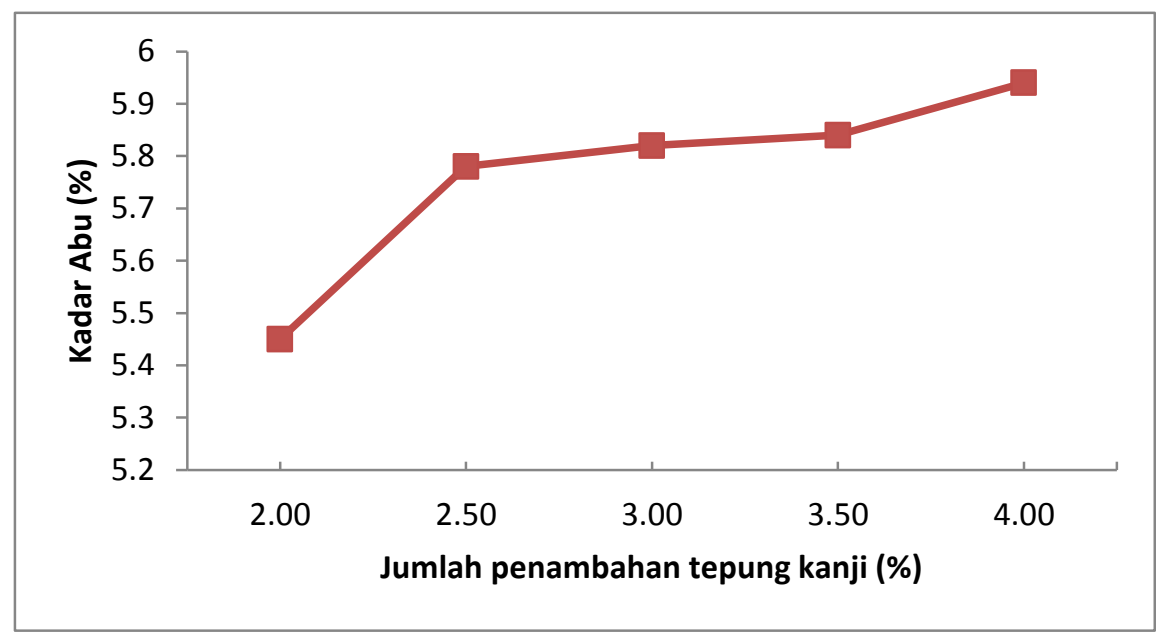

Gambar 3. Pengaruh penambahan tepung kanji terhadap kadar abu dari produk briket tempurung pala

Hasil analisis produk briket (Gambar 3) menunjukkan bahwa produk briket arang tempurung pala yang diperoleh memberikan kadar abu yang tertinggi pada perlakuan $\mathrm{E}$ dengan menggunakan perekat tepung kanji $4 \%$ yaitu sebesar $5,94 \%$ dan yang terendah diperoleh pada perlakuan $\mathrm{A}$ yang menggunakan tepung kanji $2 \%$ yaitu sebesar $5,45 \%$.

Tinggi dan rendahnya kadar abu yang diperoleh disebabkan yaitu semakin tinggi penambahan atau perekat yang digunakan tepung kanji cendrung kadar abu yang diperoleh semakin tinggi.

\section{Nilai Kalori}

Nilai kalori merupakan nilai hasil pembakaran dari sejumlah karbon aktif atau karbon terikat dalam produk briket arang dengan oksigen dalam satu gram bahan atau produk briket tempurung pala (11).

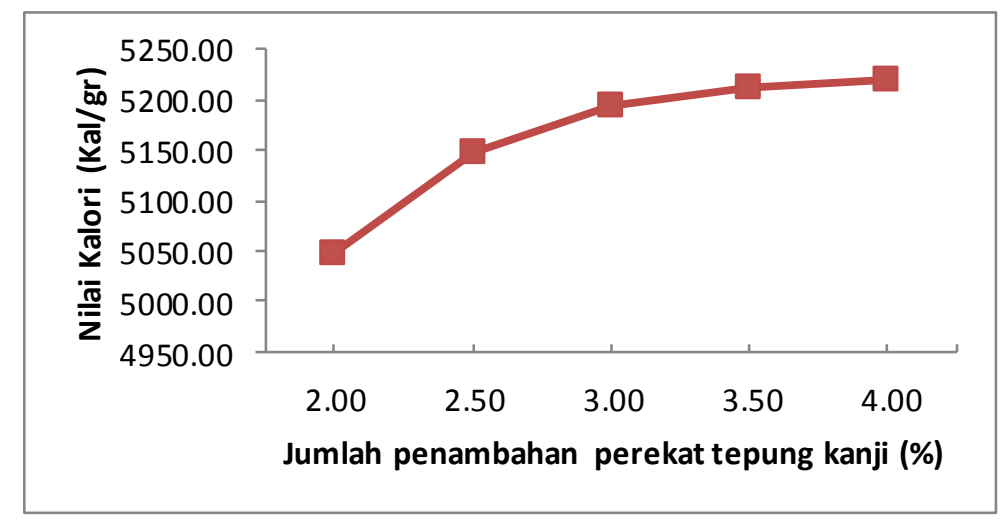

Gambar 4. Pengaruh penambahan perekat tepung kanji terhadap nilai kalori dari produk briket tempurung pala 
Gambar 4 menunjukkan bahwa produk briket arang tempurung pala memberikan hasil yang tertinggi diperoleh pada perlakuan $\mathrm{E}$ dengan menggunakan perekat atau penambahan tepung kanji sebesar $4 \%$ yaitu senilai $5219,00 \mathrm{kal} / \mathrm{g}$ dan yang terendah diperoleh pada perlakuan $A$ dengan penambahan atau perekat tepung kanji 2\% yaitu sebesar 5047,27 kal/g. Kenaikan hasil nilai kalori yang diperoleh disebabkan oleh bahan baku atau arang tempurung pala yang digunakan dengan terdiri dari partikel-partikel yang ukurannya tidak sama rata dan juga dipengaruhi oleh variasi konsentrasi penambahan perekat yang digunakan (12)

\section{KESIMPULAN}

Dari penelitian ini diperoleh bahwa arang tempurung pala dapat diolah menjadi briket dengan variasi perekat tepung kanji sebanyak 2-4\%. Briket yang dihasilkan mempunyai kisaran kadar air sebesar 6,11$6,50 \%$, bagian yang hilang pada pemanasan suhu $950{ }^{\circ} \mathrm{C}$ sebesar 14,20 $14,80 \%$, kadar abu yaitu $5,45-5,94 \%$, dan nilai kalori yaitu sebesar 5.047,27-5.219,00 $\mathrm{kal} / \mathrm{g}$, sehingga dapat digunakan sdbagai bahan bakar.

\section{DAFTAR PUSTAKA}

1. Biro Pusat Statistik Provinsi Sulawesi Utara, 2009. Sulut Dalam Angka. Biro Pusat Statistik Provinsi Sulawesi Utara.

2. Somaatmadja, 1984 Pengembangan Pengolahan Pala dan Fuli. Balai Besar Industri Hasil Pertanian Bogor.
3. Amanda JG . Marcheliana F, 2012. Kajian Potensi Lumpur Lapindo Sebagai Perekat Briket Arang Kayu Sebagai Sumber Energi Alternatif Terbarukan. Jurnal Proceeding Seminar Nasional Energy Terbarukan dan Produksi Bersih , Bandar Lampung.

4. Capahy A, 2007. Pengaruh Konsentrasi Perekat dan Ukuran Serbuk Terhadap Kualitas Briket Arang dari Limbah Pengolahan Kayu Magnium. Fakultas Pertanian Universitas Sumatera Utara.

5. Montty Grianna, 2012. Pembangunan Industri Gas Bumi, Direktur Sumber Daya Mineral, Kementrian Sumber Daya Alam dan Mineral,Jakarta.

6. Hendra, 2006. Teknologi Tepat Guna Pembuatan Arang, Briket dan Tungku Hemat Energi. Bogor: Puslitbang Hasil Hutan.

7. Jamlatan S, 2008. Sifat-Sifat Penyalaan dan Pembakaran Briket Biomassa, Briket Batu Bara dan Arang Kayu. J Rekayasa Proses;Vol 2, No.2, Hal 37-40.

8. Fatimah, Hasanuddin, H., Setiawati ,2013. Pemanfaatan Kulit Durian Sebagai Alternatif Bahan Bakar Ramah Lingkungan.

9. Patabang D, 2012. Karakteristik termal Briket Arang Sekam Padi dengan Variasi Bahan Perekat. J Mek, Vol. 3 No2 hal.286-292.

10.Nasarudin A, 2011. Karakteristik Briket dari Arang Tongkol Jagung Dengan 
Perekat Tetes Tebu dan Kanji.

Palembang: Balai Riset dan

Standardisasi Industri Palembang.

11. Mulia A, 2007. Pemanfaatan Tandan Kosong Kelapa Sawit Dan Cangkang Kelapa Sawit Sebagai Briket Arang. Medan: Universitas Sumatra Utara.

12. Santoso, 2010 Studi Variasi Komposisi Bahan Penyusun, Briket dari Kotoran Sapi dan Limbah Pertanian. Universitas Andalas. 
